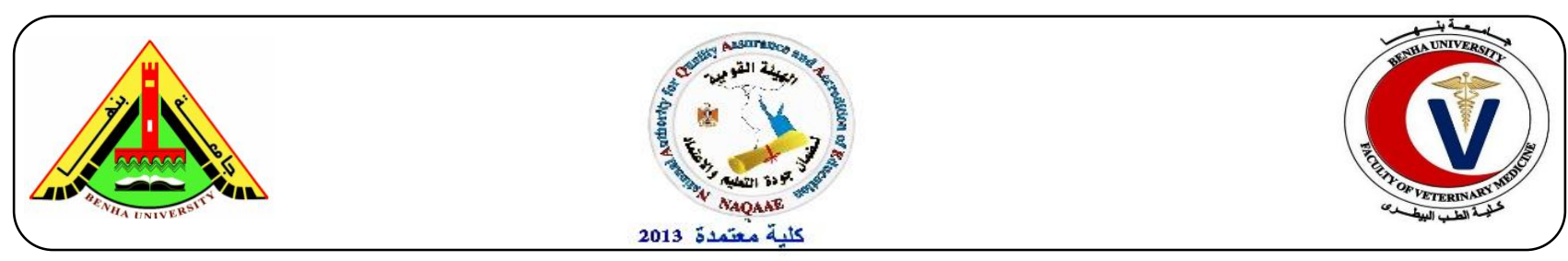

\title{
Microbiological Profile of Some Meat Products in Menofia Markets
}

\author{
Amani M. Salem ${ }^{1}$, Nahla A.Shawky ${ }^{2}$, Lamiaa M. Abo-Hussein ${ }^{2}$ \\ ${ }^{1}$ Food Control Dep., Fac. Vet. Med., Benha Univ. \\ ${ }^{2}$ Animal Health research institute, shebin el koom branch.
}

\section{A B S T R A C T}

A total of one hundred random samples of different meat products of fresh meat, minced meat, sausage and burger (25 of each) were collected from different super markets in Menoufia governorate. The mean values of APC $(\mathrm{cfu} / \mathrm{g})$ in the examined samples fresh meat, minced meat, sausage and burger were $2.15 \times 10^{7} \pm 5.36 \times 10^{6}, 2.89 \times 10^{6} \pm 5.89 \times 10^{5} 1.23 \times 10^{5} \pm 5.88 \times 10^{4}$ and $2.99 \times 10^{5} \pm 6.52 \times 10^{4}$,respectively .At the same time, Enterobacteriacea count were $2.89 \times$ $10^{4} \pm 6.99 \times 10^{3}, 7.35 \times 10^{4} \pm 3.75 \times 10^{4}, 1.50 \times 10^{3} \pm 4.88 \times 10^{2}$ and $1.60 \times 10^{3} \pm 5.51 \times 10^{2}$, While Staplyococci count were $2.18 \times 10^{4} \pm 5.86 \times 10^{3}, 8.47 \times 10^{3} \pm 3.40 \times 10^{3}, 1.95 \times 10^{3} \pm 5.14 \times$ $10^{2}$ and $1.36 \times 10^{3} \pm 5.33 \times 10^{2}$, and mould \& yeast count were $9.30 \times 10^{4} \pm 3.94 \times 10^{4}, 1.88 \times$ $10^{5} \pm 6.44 \times 10^{4}, 1.25 \times 10^{4} \pm 4.60 \times 10^{3}$ and $1.63 \times 10^{4} \pm 5.53 \times 10^{3}$ in fresh meat, minced meat, sausage and burger, respectively. The incidence of Enterobacteriacea in the examined meat product samples of fresh meat, minced meat, sausage and burger were 21(84\%), 24 (96\%), 20(80\%) and 23 (92\%). 21(84\%), 23(92\%), 20(80\%) and 20(80\%) in Staphylococci and also, 18(72\%), 19(76\%), 22(88\%) and 21(84\%) in Mould and yeast, respectively. Achieved results in the present study proved that different meat products were highly contaminated that may considered a reliable index of fecal contamination and improper handling during processing.

Key words: Minced meat, sausage, burger, APC, Staphylococci, fungi, Enterobacteriace.

(http://www.bvmj.bu.edu.eg)

(BVMJ-34(2): 1-7, 2018)

\section{INTRODUCTION}

Meat and meat products are sources of high quality protein and their amino acid composition usually compensate for shortcomings in the food. They supply easily absorbed iron and assist the absorption of iron from other foods, they also are rich sources of B-complex vitamins. (Speedy, 2003).

Poor hygienic practices in meat processing plants may result in the contamination of meat and meat products with pathogens causing a serious risk for human health. Moreover, the complete elimination of pathogens from food processing environments is a difficult, in part because bacteria can attach to meat contact surfaces where they survive even after cleaning and disinfection (Yang et al., 2012).

Aerobic plate count $(A P C)$ is the most reliable index of meat quality, sanitary processing and storage life of meat products (ICMSF, 1980), high APC of mesophilic 
bacteria, for example, when applied to raw products, often consists of the normal microflora, or perhaps indicate incipient spoilage, rather than any potential health hazard (ICMSF, 1978).

Enterobacteriaceae group has an epidemiological importance as some of its members are pathogenic and may cause serious infections and food poisoning. Moreover, the total number of Enterobacteriaceae considered as an indication of possible enteric contamination in the absence of coliforms (Mercuri et al., 1978).

Staphylococci can contaminate foods and cause illness in humans when ingested, so it is frequently implicated in food borne illness (Prange et al., 2005).

Mold and yeast comprise a large group of microorganisms which are ubiquitous in nature. Most meat spoilage by mold strains survived freezing storage of meat and produced their special effect at the favorable temperature and humidity. Contamination of meat with molds generally originated from slaughter halls and surrounding environment. Mansour et al. (1990). They are responsible for a major protein of food deterioration in developing countries. Their presence in meat is considered as an indicator of the hygienic conditions under which meat is produced and stored leading to either spoilage or food borne mycotoxicosis .

Therefore, the present study was planned out to assessment the microbiological profile of some meat products (fresh meat, minced meat, beef burger and sausage) in Menofia markets .

\section{MATERIALS AND METHODS}

\subsection{Collection of samples:}

One hundred samples of different meat products of frozen beef burger, kofta, sausage and luncheon (25 of each) were collected randomly from different supermarkets in Menofia governorate to be examined microbiologically for detection of some food poisoning microorganisms. Each sample was kept in a separate sterile plastic bag and preserved in an ice box, then transferred to the laboratory under possible aseptic conditions without undue delay and examined as quickly as possible.

2.2 Microbiological analysis:

\subsubsection{Preparation of sample (APHA,} 2001):

Twenty-five grams of the examined meat products were transferred to a sterile blender jar and $225 \mathrm{ml}$ of $0.1 \%$ sterile buffered peptone water were aseptically added to the content of the jar. Each sample was then homogenized in the blender at 2000 r.p.m for 1-2 minutes to provide a homogenate, from which tenth - fold serial dilutions were prepared. The prepared samples were subjected to the following examination:

\subsubsection{Detection of APC:}

It was carried out according to (ICMSF, 1996)

2.2.3 Detection of Enterobacteriaceae count:

It was carried out according to (ICMSF, 1996)

2.2.4Detection of staphylocooci count:

It was carried out according to (ICMSF, 1996)

2.2.5 Detection of mould and yeast Count:

It was carried out according to (APHA, 1966)

2.3. Statistical Analysis (Snedecor and Cochran, 1967).

\section{RESULTS}

It is evident from the results recorded in Table (1), that the mean values of APC (cfu/g) in the examined samples of meat products were $2.15 \times 10^{7} \pm 5.36 \times 10^{6}$ in fresh meat, $2.89 \times 10^{6} \pm 5.89 \times 10^{5}$ in minced meat, $1.23 \times 10^{5} \pm 5.88 \times 10^{4}$ in sausage and $2.99 \times$ 
$10^{5} \pm 6.52 \times 10^{4}$ in Burger. On the other hand, the mean values of the examined samples of fresh meat, minced meat, sausage and burger were $2.89 \times 10^{4} \pm 6.99 \times 10^{3}, 7.35 \times 10^{4} \pm$ $3.75 \times 10^{4}, 1.50 \times 10^{3} \pm 4.88 \times 10^{2}$ and $1.60 \times$ $10^{3} \pm 5.51 \times 10^{2}(\mathrm{cfu} / \mathrm{g})$, respectively for Enterobacteriacae. Also the mean values of Staphylococci(cfu/g) in fresh meat, minced meat, sausage and burger were $2.18 \times 10^{4} \pm$ $5.86 \times 10^{3}, 8.47 \times 10^{3} \pm 3.40 \times 10^{3}, 1.95 \times 10^{3}$ $\pm 5.14 \times 10^{2}$ and $1.36 \times 10^{3} \pm 5.33 \times 10^{2}$, respectively. The mean values of mould and yeast counts $(\mathrm{cfu} / \mathrm{g})$ observed in fresh meat was $9.30 \times 10^{4} \pm 3.94 \times 10^{4}$, followed by
$1.88 \times 10^{5} \pm 6.44 \times 10^{4}$ in minced meat, 1.25 $\times 10^{4} \pm 4.60 \times 10^{3}$ in sausage, and $1.63 \times$ $10^{4} \pm 5.53 \times 10^{3}$ in burger.

Result in table (2) declared that , $32 \%, 48 \%, 40 \%$ and $56 \%$ were accepted according to the Egyptian standard (2005) for APC $\left(10^{6} / \mathrm{g}\right)$, while for Enerobacteriace were $16 \%, 24 \%, 20 \%$ and $8 \%$ were accepted according to EOS (2005), on the other hand, $16 \%, 8 \%, 20 \%$ and $20 \%$ accepted according to EOS (2005) for Staphylococci, and, 28\%, $24 \%, 12 \%$ and $16 \%$ were accepted according to EOS (2005) for mould and yeast .

Table(1) Mean values (cfu/g) of microbial load in the examined meat products samples $(n=25)$.

S.E : Standered error .

APC Enterobacteriace

Staphylococci

Mould\&yeast

product

\begin{tabular}{lllllll}
\hline Mean \pm & + VE & Mean & +VE & Mean & +VE & Mean \pm S.E. \\
S.E. & SAMPL & \pm S.E. & SAMPLE & \pm S.E. & SAMPLE & \\
& $\mathrm{E}$ & & & \\
& & NO $\%$ & & NO $\%$
\end{tabular}

\begin{tabular}{|c|c|c|c|c|c|c|c|c|c|c|}
\hline $\begin{array}{l}\text { Fresh } \\
\text { meat }\end{array}$ & $\begin{array}{r}2.15 \times 10^{7} \pm \\
5.36 \times 10^{6}\end{array}$ & 21 & $\begin{array}{l}8 \\
4\end{array}$ & $\begin{array}{c}2.89 \times 10^{4} \\
\pm 6.99 \times \\
10^{3}\end{array}$ & 21 & $\begin{array}{l}8 \\
4\end{array}$ & $\begin{array}{c}2.18 \times 10^{4} \pm \\
5.86 \times 10^{3}\end{array}$ & 18 & 72 & $\begin{array}{c}9.30 \times 10^{4} \pm \\
3.94 \times 10^{4}\end{array}$ \\
\hline $\begin{array}{l}\text { Minced } \\
\text { meat }\end{array}$ & $\begin{array}{r}2.89 \times 10^{6} \pm \\
5.89 \times 10^{5}\end{array}$ & 24 & $\begin{array}{l}9 \\
6\end{array}$ & $\begin{array}{c}7.35 \times 10^{4} \\
\pm 3.75 \times \\
10^{4}\end{array}$ & 23 & $\begin{array}{l}9 \\
2\end{array}$ & $\begin{array}{c}8.47 \times 10^{3} \pm \\
3.40 \times 10^{3}\end{array}$ & 19 & 76 & $\begin{array}{c}1.88 \times 10^{5} \pm \\
6.44 \times 10^{4}\end{array}$ \\
\hline sausage & $\begin{array}{c}1.23 \times 10^{5} \pm \\
5.88 \times 10^{4}\end{array}$ & 20 & $\begin{array}{l}8 \\
0\end{array}$ & $\begin{array}{c}1.50 \times 10^{3} \pm \\
4.88 \times 10^{2}\end{array}$ & 20 & $\begin{array}{l}8 \\
0\end{array}$ & $\begin{array}{c}1.95 \times 10^{3} \pm \\
5.14 \times 10^{2}\end{array}$ & 22 & 88 & $\begin{array}{c}1.25 \times 10^{4} \pm \\
4.60 \times 10^{3}\end{array}$ \\
\hline burger & $\begin{array}{c}2.99 \times 10^{5} \pm \\
6.52 \times 10^{4}\end{array}$ & 23 & $\begin{array}{l}9 \\
2\end{array}$ & $\begin{array}{c}1.60 \times 10^{3} \\
\pm 5.51 \times \\
10^{2}\end{array}$ & 20 & $\begin{array}{l}8 \\
0\end{array}$ & $\begin{array}{c}1.36 \times 10^{3} \pm \\
5.33 \times 10^{2}\end{array}$ & 21 & 84 & $\begin{array}{c}1.63 \times 10^{4} \pm \\
5.53 \times 10^{3}\end{array}$ \\
\hline
\end{tabular}

\section{Significant at $1 \%$}

Table (2): Acceptability of bacterial load in the examined samples of meat products according to permissible limits of E.O.S (2005)

APC Enterobacteriace $\quad$ Staphylococci $\quad$ Mould\&yeast




\begin{tabular}{llllllllll}
\hline Product & $\begin{array}{l}\text { Acceptable } \\
\text { samples }\end{array}$ & \multicolumn{2}{l}{$\begin{array}{l}\text { Acceptable } \\
\text { samples }\end{array}$} & & \multicolumn{2}{l}{$\begin{array}{l}\text { Acceptable } \\
\text { samples }\end{array}$} & \multicolumn{3}{l}{$\begin{array}{l}\text { Acceptable } \\
\text { samples }\end{array}$} \\
\cline { 2 - 10 } & No & $\%$ & No & $\%$ & No & $\%$ & No & $\%$ \\
\hline Fresh meat & 8 & $32 \%$ & 4 & $16 \%$ & 4 & $16 \%$ & 7 & $28 \%$ \\
$\begin{array}{l}\text { Minced } \\
\text { meat }\end{array}$ & 12 & $48 \%$ & 6 & $24 \%$ & 2 & $8 \%$ & 6 & $24 \%$ \\
sausage & 10 & $40 \%$ & 5 & $20 \%$ & 5 & $20 \%$ & 3 & $12 \%$ \\
burger & 14 & $56 \%$ & 2 & $8 \%$ & 5 & $20 \%$ & 4 & $16 \%$ \\
\hline
\end{tabular}

*Permissible limits of Apc for fresh meat , minced meat and sausage $\left(10^{6}\right)$ and burger $\left(10^{5}\right)$

*Permissible limits of enterobacteriace and staphylococci $\left(10^{2}\right)$

*Permissible limits of mould and yeast (free)

\section{DISCUSSION}

Meat products are perishable foods and unless stored under proper conditions spoil quickly. In addition, if pathogens are present, meat products become hazardous for consumers. Therefore, assurance of meat safety and quality is the most important (Shimoni and Iabuza, 2000).

Results demonstrated that fresh meat highly contaminated these results agreed with those of (Biswas et al., 2008), where they reported that, the fresh meat of a high incidences to bacterial contamination followed by minced meat, burger and sausage. The clothes of workers, processing equipment and water used to wash carcass, hands and equipment were source of meat contamination during slaughter process. (Upmann et al., 2000). The sources could be the animal, the environment or contamination during meat processing (McNamara 1998). The main source of meat contamination is animal feces especially during processing at the slaughterhouse (Kudva et al., 1998).

According to results achieved in table (1) Comparing the obtained values from the examined samples, higher result for APC,
Staphylococci and Enterobacteriace count were reported by Tekinşen et al. (1980)(8.4x10 $\mathrm{cfu} / \mathrm{g}$.),Gönülalan and Köse (2003) $\left(5.3 \times 10^{9} \mathrm{cfu} / \mathrm{g}.\right)$ and Başkaya et al. $(2004)\left(6.3 \times 10^{7} \mathrm{cfu} / \mathrm{g}\right.$.) in minced meat in APC. While, Ibrahim (2016) who found that Staphylococci counts (cfu/g) of examined sausage, beef burger and minced meat samples were $1.97 \times 10^{5} \pm 6.49 \times 10^{4}, \quad 2.08$ $\mathrm{x} 10^{5} \pm 5.56 \times 10^{4}$ and $5.83 \times 10^{5} \pm 1.06 \times 10^{5}$, respectively. Also, higher ones for Staphylococci showed by Abou- Hussien$(2004)\left(5.38 \times 10^{5} \pm 9.7 \times 10^{4} \mathrm{cfu} / \mathrm{g}\right)$ in frozen sausage and Talaat (2009) $\left(6.92 \times 10^{6} \pm 4.54 \mathrm{x}\right.$ $\left.10^{6} \mathrm{cfu} / \mathrm{g}\right)$ in frozen minced meat. AI-Mutairi (2011) $\left(37.8 \times 10^{4} \mathrm{CFU} / \mathrm{g}\right.$ in sausage for Enterobacteriace).

On other hand, lower results were recorded by Hasanein et al.(2015) found that The mean values of APC, and staphylococcus counts $(\mathrm{cfu} / \mathrm{g})$ were $7.34 \times 10^{4} \pm 1.22 \times 10^{4}$ and $1.57 \mathrm{x}$ $10^{3} \pm 0.36 \mathrm{x} 10^{3}$ in beef burger. Also, lower results for APC were reported by Salem et al. (2010) (5.61 x $10^{5} \mathrm{cfu} / \mathrm{g}$.), Melngaile et al., (2014) (5.08 $\log \mathrm{cfu} / \mathrm{g}$.$) \& Elabbasy et al.$ (2014) (5.82 log cfu/g.) in minced meat, ELMossalami (2009) $\left(3.2 \pm 1.6 \times 10^{4} \mathrm{cfu} / \mathrm{g}\right.$. $)$ in 
sausage. And alco, El-Dosoky et al. (2013)( $3.6 \pm 2 \log \mathrm{cfu} / \mathrm{g}$.) in sausage . Ahmed (2018) reveled that Enterobacteriaceae counts varied from $4.0 \times 10^{2}$ to $6.4 \times 10^{4}$ with mean value of $5.82 \times 10^{3} \pm 1.02 \times 10^{3}$ in minced meat. Hegazi et al. (1992) found that The mean values of fungal count $(\mathrm{cfu} / \mathrm{g})$ were $1.0 \times 10^{2}$ in fresh meat, $\quad 9.50 \times 10^{2}$ in sausage, $1.75 \times 10^{2}$ in minced meat and $4.15 \times 10^{2}$ in burger .Moreover, Sayed (2006) found that the mean values of fungal count raw and meat minced meat were $5.96 \times 10^{3} \pm 5.17 \times 10, \quad 6.78$ $\mathrm{x} 10^{3} \pm 6.14 \times 10$, respectively.

while it is evident from the results recorded in Table (1) that there is nearly similar results obtained by Abd El-Hamid (2010) revealed that the mean values of Staphylococcal count were $2.17 \times 10^{3} \pm 4.31$ $\times 10^{2}$ and $2.2 \times 10^{3} \pm 4.54 \times 10^{2}(\mathrm{cfu} / \mathrm{g})$ in burger and sausage. Also, Ahmed (2018) reveled that Enterobacteriaceae counts $(\mathrm{cfu} / \mathrm{g})$ were $4.15 \times 10^{3} \pm 1.36 \times 10^{3}$ in beef burger and $3.91 \times 10^{3} \pm 3.15 \times 10^{3}$ in sausage . Also , these results nearly agreed with Ayten K. et al. (2014) they recorded that the molds and yeasts count ranged from $7 \times 10^{3}$ to $4 \times 10^{8} \mathrm{cfu} / \mathrm{g}$ in fresh meat and El-Tawab (2014) $\left(7.63 \times 10^{4} \pm 1.79 \times 10^{4}\right.$ in sausage and $3.06 \times 10^{4} \pm 0.92 \times 10^{4} \mathrm{cfu} / \mathrm{g}$ in burger ).

As shown in table (2) results indicated that the presence of APC, Enterobacteriace, Staphylococci and mould \& yeast in examined samples more than permissible limits of EOS (2005) in such meat products represent a high risk to consumer, cause health hazard and indicates inadequate sanitary conditions during stages of manufacturing, dirty equipment and improper handling.

\section{CONCLUSION}

Achieved results in the present study proved that fresh meat was the highly contaminated product that may considered a reliable index of fecal contamination and improper handling during processing. While, sausage was the lowest contaminated due to heat treatment and adding of spicy .

Consequently, strict maintenance of good practices during processing, strengthened by maintaining the cold chain during transport, distribution and carcass commercialization is of central importance to ensure both public health and food quality .

\section{REFERENCES}

Abd El-Hamid, M. A. (2010): Detection of some food poisoning microorganism in some meat products.M.V.Sc. Thesis, Fac. Vet. Med., Alex. Univ Egypt.

Abou Hussein-Reham, A. A. (2004): "Microbial Evaluation of Some Meat Products", M. V. Sci. Thesis (Meat Hygiene), Fac. Vet. Med., Zagazig Univ. (Benha Branch) Egypt.

Ahmed M. H. Youness (2018) : Bacteriological status of some meat products . M. V. Sci. Thesis (Meat Hygiene), Fac. Vet. Med., Benha Univ. Egypt.

AI-Mutairi,M.F.(2011): The Incidence of Enterobacteriaceae Causing food Poisoning in some meat products. J. of food Sci. and Technol., 3 (2): 116-121.

"APHA " American Public Health Association " (1966) : Recommendation Methods for the Microbiological Examination of Foods. Ed. New York.

"APHA" (American Public Health Association) (2001): Compendium of methods for microbiological examination of foods. 4th Edition 365366- 800. 1st, NW Washington DC2000 1-3710.

Aydin, A.; Sudagidan, M. and Muratoglu, K. (2011): Prevalence of staphylococcal enterotoxins, toxin genes and geneticrelatedness of foodborne $S$. aureus strains isolated in the Marmara Region 
of Turkey. Int. J. Food Microbiol., 148

(2): 99-106.

Ayten, K. E.; Duygu, S.;Didem, O. and Ezgi, O. ( 2014) : Microbiological Quality of Minced Meat Samples Marketed in Istanbul YYU Veteriner Fakultesi Dergisi, 25 (3): 67 - 70 ISSN: 1017-8422; e-ISSN: 1308-3651.

Başkaya, R., Karaca; T., Sevinç; İ., Çakmak, Ö.; Yıldı, A. and Yörük, M. (2004):İstanbul'da satışa sunulan hazır kıymaların histolojik, mikrobiyolojik ve serolojik kalitesi. YYÜ Vet Fak Derg., 15: 41-46.

Biswas, A.K.; Kondaiah, N.; Bheilegaonkar, K.N.; Anjaneyulu, A.S.R.; Mendiratta, S.K.; Jana, C.; Singh, H. and Kuma, R.R. (2008):Microbial profiles of frozen trimmings and silver sides prepared at Indian buffalo meatpacking plants. Meat Sci. , 80:418-422.

Center for Food Safety "CFS" (2014): Microbiological Guidelines for Food (For ready-to-eat food in general and specific food items). Risk Assessment Section, Food and Environmental Hygiene Department43/F, Queensway Government Offices, 66 Queensway, Hong Kong.

El-Dosoky, H.F.A., Shafik,S. and Baher, M.(2013): Detection of spoilage and food poisoning bacteria in some ready to eat meat products in Dakahlia governorate.Assiut Vet.Med.J.,59:5559.

El-Mossalami, H.H.A.; AbdeL-Rahman, A.A. and Magdy, E.M. (2009): A study on the effect of Garlic and Nigella sativa on some food poisoning bacteria isolated from ready-to-eat meat sandwiches in Alexandria City. Assiut Vet. Med. J., 54: 140-158.

El-Tawab, M.M. (2014): Studies on mycotoxins in some meat products.
M.V.Sc.( Meat Hygiene), Fac. Vet. Med., Benha Univ. Egypt.

Egyptian Organization for Standardization and Quality (2005): Egyptian Standard, ES.

Gönülalan, Z. and Köse, A. (2003): Kayseri ilinde satışa sunulan sığır kıymalarının mikrobiyolojik kalitesi. FÜ Sağlık Bil Derg., 17:49-53.

Hassanien, Fatin S.; Mohamed, A. H. ElShater and Rabab R. Abd El-Fatah (2015) Bacteriological aspect of meat and poultry meat meals. BENHA VET. MED. J., 28 (2):91-97.

Hegazi, S.M. ; El-Far, F. ;Edries, A. M. and Aziz, N.H. (1992): Studies of foungal and aflatoxins contamination of meat, meat product and food additives. Vet. Med. J. Giza, 40 :31 - 36 Egypt.

International Commission on Microbiological Specification for Foods "ICMSF" (1980) "Microbial ecology of foods". Vol. 1, Academic Press, New York, Toronto.

International Commission on Microbiological Specification for Foods "ICMSF" (1978): Microorganisms in foods. Their significance and methods of enumeration. 2nd Ed. University of Toronto Press. Toronto Canada.

International commission of Microbiological Specification for foods"ICMSF"(1996):

Microorganisms in Food. I-Their Significance and methods of enumeration. 3rd Ed. Univ. of Toronto, Canada.

Kudva, T.; Blanch, K. and Hovde, C.J.( 1998): Analysis of Escherichia coli O157:H7 survival in ovine or bovine manure and manure slurry. Appl Environ Microb. , 64:3166-3174.

Mansour, N. ; Hamdy, M. ; Yassien, N. and Refai, M. (1990) : Dematiaceous hyphomycetes in Salughtered camels, 
cattle and surroundings at Cairo abattoir. Assiut Vet. Med., J. 24 : 145.

McNamara, A.M. (1998):Foodborne pathogens. J Urban Health. 75:503505. doi: 10.1007/BF02427690.

Melngaile,A.; Ciekure,E. and Valcina,O. (2014): Microbiological quality of meat preservation and meat products. Food Balt., 61:65.

Mercuri, A.J.; Cox, N.A.; Carson, M.O. and Tanner, D.A. (1978): Relation of Enterobacteriaccae count to Salmonella contamination of Marker broiler. J. Food Protect., 42:427.

Prange, A.; Birzele, B.; Hormes, J. and Modrow, H. (2005):Investigation of different human pathogenic and food contaminating bacteria and mould grown on Selenite/ Selenate and Tellurite / Tellurate by-x ray absorption spectroscopy. Food Control, 16: 713728.

Salem, Amany M.; Amin, Reham A. and Afifi, Gehan S.A.(2010): Studies on antimicrobial and antioxidant efficiency of some essential oils in minced beef .J. American Sci., 6:691700 .

Sayed, A.A.K. (2006): Monitoiring and control of mycotoxins producing fungi in Assuit city hospitals resturants . Ph. D. Thesis , Fac. Vet. Med., Assiut Univ., Egypt .

Scallan, E.; Griffin, P.M.; Angulo, F.J.;Tauxe ,R.V.; Hoekstra, R.M.(2011): Foodborne illness acquired in the United States-unspecified
agents.Emerg Infect Dis. 17:16-27. doi: 10.3201/eid1701.P21101.

Shimaa M. A.Ibrahim (2016) : Detection of Staphylococcus aureus classic enterotoxin genes in some meat products using multiplex PCR. Ph.D Thesis, Fac. Vet. Med., Kafrelsheikh Univ. Egypt.

Shimoni .E. and Iabuza T. P.( 2000) :Modeling pathogen growth in meat products : future challenges . Trends in food science and Technology 11(11) : 394.

Snedecor,G. W. and Cochran, W.G. (1967):"Statistical Methods". $6^{\text {th }}$ Ed. Oxford Publishing Company, London.

Speedy, A.W. (2003): Global production and consumption of animal source foods. J. Nutr., 133(11): 4048S-4053S.

Talaat-Nagwa, W. (2009): Bacteriological and histological evaluation of some meat products. M.V.Sc.(Meat hygiene), Fac. Vet. Med., Karelsheikh Univ. Egypt.

Tekinşen, O.C; Yurteri, A. and Mutluer, B. (1980):Ankara'da satılan hazır kıymaların bakteriyolojik kalitesi. AÜ Vet Fak Derg., 27: 45-63.

Upmann, Jvl.;Jakob, P. and Reuter, G.(2000): Microbial transfer during cutting and deboning of pork. Dairy food and Environmental Sanitation, 20:14:23.

Yang, L.; Liu, Y.; Wu, H.; Song, Z.; Høiby, N.; Molin, S. and Givskov, M. (2012): Combating biofilms. FEMS Immunol. Med. Microbiol., 65(2):146-157 